\title{
МОРФОМЕТРИЧНА ОЦІНКА ОСОБЛИВОСТЕЙ РЕМОДЕЛЮВАННЯ ГЕМОМІКРОЦИРКУЛЯТОРНОГО РУСЛА СІМ'ЯНИКІВ ПРИ ДІЇ НА ОРГАНІЗМ РУБОМІЦИНУ гІДРОХЛОРИДУ
}

\author{
ФМ. С. Гнатюк, С. О. Коноваленко, Л. В. Татарчук
}

Тернопільський національний медичний університет імені І. Я. Горбачевського МОз України

РЕЗЮМЕ. Відомо, що рубоміцин - протипухлинний антибіотик з вираженою цитостатичною дією - широко використовується у клініці $[1,2]$. Застосування цього медикаментозного препарату в чоловіків може ускладнитися азооспермією, у морфогенезі якої важлива роль належить гемомікроциркуляторному руслу сім'яників.

Мета - провести морфометричний аналіз особливостей ремоделювання судин гемомікроциркуляторного русла сім'яників при дії на організм рубоміцину гідрохлориду.

Матеріал і методи. Морфометрично досліджено гемомікроциркуляторне русло сім'яників 60 білих щурівсамців, які були поділені на дві групи. 1 група включала 30 інтактних тварин, 2 - 30 щурів, яким одноразово внутрішньоочеревинно вводили рубоміцину гідрохлорид у дозі 30 мг/кг. Евтаназію дослідних тварин здійснювали кровопусканням в умовах тіопенталового наркозу через місяць від початку експерименту.

Морфометрично визначали діаметри артеріол, передкапілярних артеріол, гемокапілярів, закапілярних венул, венул, а токож щільність мікросудин на 1 мм² сім'яників. Кількісні показники обробляли статистично.

Встановлено, що морфометричні параметри мікросудин гемомікроциркуляторного русла сім'яників при дії на організм рубоміцину гідрохлориду суттєво змінювалися. Діаметр артеріол сім'яників при цьому зменшився на 17,0 \%, передкапілярних артеріол - на 22,4 \%, гемокапілярів - на 15,8 \% (р<0,001), а просвіт закапілярних венул розширився на 31,1 \%, венул - на 26,8 \%, щільність мікросудин зменшилася на 27,2 \%. Виявлене свідчить про погіршання кровопостачання досліджуваного органа. Світлооптично переважна більшість венозних судин гемомікроциркуляторного русла нерівномірно розширені, варикозно змінені, з частими саккуляціями, переповнені форменими елементами крові, з явищами стазу, тромбозу, що свідчить про виражене порушення їх дренажної функції. Венозний застій у досліджуваних судинах призводив до посилення гіпоксії, дистрофії та некрозів ендотеліоцитів, міоцитів, сперматогенних епітеліоцитів, стромальних структур, інфільтративних та склеротичних процесів.

Висновки. Введення в організм дослідних тварин рубоміцину гідрохлориду призводить до вираженого ремоделювання судин гемомікроциркуляторного русла сім'яників, яке характеризується вираженим звуженням просвітів артеріол, передкапілярних артеріол, гемокапілярів і розширенням закапілярних венул та венул, змінами ангіоархітектоніки мікросудин, венозним повнокров'ям, дисторофією, некробіозом клітин і тканин, інфільтративними та склеротичними процесами.

КлючовІ СлОВА: рубоміцину гідрохлорид; сім'яники; гемомікроциркуляторне русло.

Вступ. Відомо, що рубоміцин (даунорубіцин) - протипухлинний антибіотик антрациклінового ряду з вираженою цитостатичною дією широко використовується у клініці [2]. Застосування цього медикаментозного препарату може призводити до різних порушень у функціонуванні серцево-судинної, дихальної, травної, кровотворної систем. У чоловіків репродуктивна система під впливом рубоміцину гідрохлориду може ускладнитися азооспермією (відсутністю сперматозоїдів в еякуляті) $[6,7]$.

Судини гемомікроциркуляторного русла, де проходить транскапілярний обмін, відіграють важливу роль у трофічному забезпеченні клітин та тканин і у патоморфогенезі їх ушкоджень. Варто вказати, що особливості ремоделювання гемомікроциркуляторного русла сім'яників при дії на організм рубоміцину гідрохлориду досліджені недостатньо. Відомо також, що функціональноструктурні зміни у судинах гемомікроциркуляторного русла $\epsilon$ першими ранніми ознаками при впливах на організм негативних факторів ендогенного та екзогенного походження $[3,4]$.

Мета - провести морфометричний аналіз особливостей ремоделювання судин гемомікроциркуляторного русла сім'яників при дії на організм рубоміцину гідрохлориду.

Матеріали і методи. Комплексом морфологічних методів досліджені сім'яники 60 статевозрілих білих щурів-самців, які були поділені на дві групи. 1 група (контрольна) включала 30 тварин, які перебували у звичайних умовах віварію, 2 30 щурів, яким одноразово внутрішньоочеревинно вводили рубоміцину гідрохлорид у дозі 30 мг/кг [7]. Евтаназію дослідних тварин здійснювали кровопусканням в умовах тіопенталового наркозу через місяць від початку експерименту.

Гемомікроциркуляторне русло сім'яників вивчали за допомогою наповнення їх судин туш-желатиновою сумішшю, яку вводили через черевну аорту. Через 3-4 години після заповнення кровоносного русла сім'яників вказаною сумішшю про- 
Огляди літератури, оригінальні дослідження, погляд на проблему, випадок з практики, короткі повідомлення водили їх забір і фіксували в 10 \% розчині нейтрального формаліну впродовж 2 тижнів. На заморожуючому мікротомі виготовляли зрізи товщиною 30-40 мкм, які зневоднювали в етилових спиртах зростаючої концентрації, просвітлювали у метиловому ефірі саліцилової кислоти і поміщали у полістирол. Виготовлені за вказаною методикою мікропрепарати досліджували за допомогою бінокулярного мікроскопа МБР-3 при різних збільшеннях. Із частини сім'яників із заповненими туш-желатиновою сумішшю судинами виготовляли гістологічні препарати, забарвлені гематоксиліном-еозином [5]. Морфометрично визначали діаметри артеріол (ДА), передкапілярних артеріол (ДПА), гемокапілярів (ДГ), закапілярних венул (ДЗВ), венул (ДВ) та щільність

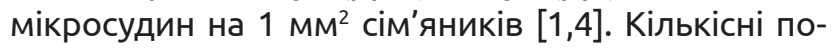
казники обробляли статистично. Обробка отриманих результатів виконана у відділі системних статистичних досліджень Тернопільського національного медичного університету імені І. Я. Горбачевського МО3 України в програмному пакеті STATISTICA. Різницю між порівнюваними величинами визначали за критеріями Стьюдента та Манна-Уїтні [8]. Експерименти та евтаназію дослідних тварин проводили з дотриманням «Загальних етичних принципів експериментів на тваринах», ухвалених Першим національним конгресом з біоетики (Київ, 2001) відповідно до «Європейської конвенції про захист хребетних тварин, що використовуються у дослідних та інших наукових цілях», а також Закону України «Про захист тварин від жорстокого поводження» (від 21.02.2006) [9].

Результати й обговорення. Результати проведеного дослідження представлені в таблиці 1.

Таблиця 1. Морфометрична характеристика гемомікроциркуляторного русла сім'яників дослідних тварин $(\mathrm{M} \pm \mathrm{m})$

\begin{tabular}{|l|c|c|}
\hline \multirow{2}{*}{\begin{tabular}{|c|} 
Показник \\
\cline { 2 - 3 }
\end{tabular}} & 1 & 2 \\
\cline { 2 - 3 } ДА, мКм & $18,20 \pm 0,30$ & $15,10 \pm 0,21^{* * *}$ \\
\hline ДПА, мКм & $10,82 \pm 0,12$ & $8,40 \pm 0,06^{* * *}$ \\
\hline ДГ, мКм & $6,12 \pm 0,09$ & $5,15 \pm 0,05^{* * *}$ \\
\hline ДЗВ, мКм & $12,58 \pm 0,15$ & $16,50 \pm 0,18^{* * *}$ \\
\hline ДВ, мКм & $26,57 \pm 0,30$ & $33,70 \pm 0,36^{* * *}$ \\
\hline ЩМ & $3843,3 \pm 28,2$ & $2795,6 \pm 22,5^{* * *}$ \\
\hline
\end{tabular}

Примітка. *** - p<0,001, порівняно з 1 групою.

У результаті всестороннього аналізу даних вказаних у таблиці, встановлено, що морфометричні параметри мікросудин гемомікроциркуляторного русла у 2 групі спостережень (дія на організм рубоміцину гідрохлориду) виявилися суттєво зміненими, порівняно з контрольними спостереженнями. Діаметр артеріол сім'яників контрольної групи тварин дорівнював $(18,20 \pm 0,30)$ мкм, а при дії на організм рубоміцину гідрохлориду - $(15,10 \pm$ $0,21)$ мкм. Наведені морфометричні показники між собою статистично достовірно $(p<0,001)$ відрізнялися. При цьому останній морфометричний параметр виявився меншим за попередній на $17,0 \%$. Аналогічно змінювалися у даних експериментальних умовах також діаметри передкапілярних артеріол.

У 2 групі дослідних тварин діаметр передкапілярних артеріол дорівнював $(8,40 \pm 0,06)$ мкм. Наведений морфометричний параметр з вираженою статистично достовірною різницею $(p<0,001)$ відрізнявся від такого ж кількісного морфометричного показника у контрольних спостереженнях $(10,82 \pm 0,12)$ мкм. Виявлена різниця між наве- деними морфометричними параметрами склала майже $22,4 \%$.

Діаметр гемокапілярів сім'яників у контрольних спостереженнях дорівнював $(6,12 \pm 0,09)$ мкм, а у дослідних тварин, яким вводили рубоміцину гідрохлорид - $(5,15 \pm 0,05)$ мкм. Між наведеними морфометричними параметрами виявлена статистично достовірна різниця $(p<0,001)$ і останній кількісний морфологічний показник виявився меншим за попередній на 15,8 \%.

У результаті проведених морфометричних досліджень встановлено, що венозна частина гемомікроциркуляторного русла сім'яників у змодельованих експериментальних умовах розширювалася. При цьому просвіт закапілярних венул статистично достовірно $(p<0,001)$ збільшився на $31,1 \%$, а венул - на 26,8 \% $(p<0,001)$. Змінювалася у вказаних умовах досліду також щільність мікросудин на 1 мм² тканини. У контрольних спостереженнях цей морфометричний показник дорівнював $(3843,3 \pm 28,2)$, а у 2 групі спостережень - $(2795,6 \pm 22,5)$. Наведені кількісні морфологічні параметри статистично достовірно $(p<0,001)$ відрізнялися між собою і остан- 
Огляди літератури, оригінальні дослідження, погляд на проблему, випадок з практики, короткі повідомлення ній показник виявився меншим за попередній на 27,2 \%. Знайдене свідчило про погіршання кровопостачання досліджуваного органа.

Світлооптично виявлено, що венозні судини розширені, переповнені кров'ю. Відмічався також перивазальний набряк, який місцями звужував та деформував досліджувані судини. Змінювалася просторова орієнтація мікросудин, тобто їх ангіоархітектоніка. Переважна більшість венозних судин гемомікроциркуляторного русла були нерівномірно розширені, варикозно змінені, з частими саккуляціями, переповнені форменими елементами крові, з явищами стазу, тромбозу, що свідчило про виражене порушення їх дренажної функції [6]. Венозний застій у досліджуваних судинах призводив до посилення гіпоксії, дистрофії та некрозів ендотеліоцитів, міоцитів, сперматогенних епітеліоцитів, стромальних структур, інфільтративних та склеротичних процесів [3,4].

\section{ЛІТЕРАТУРА}

1. Автандилов Г. Г. Основы количественной патологии / Г. Г. Автандилов. - М. : Медицина, 2002. - 240 с.

2. Бурбела А. Т. Современные лекарственные средства / А. Т. Бурбела, А. В. Шабров, П. П. Денисенко. - М. : Олма-Пресс, 2003. - 862 с.

3. Возняк І. Я. Порушення мікроциркуляції і системи гемостазу у хворих на хронічні дерматози / І. Я. Возняк, О. А. Білинська // Клінічна медицина. - 2012. № 1. - C. 33-36.

4. Гнатюк М. С. Морфометричний аналіз ремоделювання гемомікроциркуляторного русла порожньої кишки при резекціях печінки / М. С. Гнатюк, Л. В. Татарчук // Вісник морфології. - 2018. - Т. 24, № 1. C. $16-20$.

5. Горальський Л. П. Основи гістологічної техніки і морфофункціональні методи досліджень у нормі та

\section{REFERENCES}

1. Avtandilov, G.G.(2002). Osnovy kolichestviennoy patologicheskoy anatomii [Basis of quantitative pathological anatomy]. Moscow: Meditsyna [in Russian].

2. Burbela, A.T., Shabrov, A.V., \& Denisenko, P.P. (2003). Sovremennye lekarstvennye sredstva [Modern drugs]. Moscow: Olma-Ptess [in Russian].

3. Vozniak, I.Ya., \& Bilynska, O.A. (2012). Porushennia mikrotsyrkulyatsii i systemy hemostazu u khvorykh na khronichni dermatozy [Disorders of microcirculation and hemostasis in patients with chronic dermatoses]. Klinichna medytsyna - Clinical Medicine, 1, 33-36 [in Ukrainian].

4. Hnatiuk, M.S., \& Tatarchuk, L.V. (2018). Morfometrychnyi analiz remodeliuvannia hemomikrotsyrkuliatornoho rusla porozhnoi kyshky pry rezektsiiakh pechinky [Morphometric analysis of remodeling of the hemomicro-

Висновок. Введення в організм дослідних тварин рубоміцину гідрохлориду призводить до вираженого ремоделювання судин гемомікроциркуляторного русла сім'яників, яке характеризується вираженим звуженням просвітів артеріол, передкапілярних артеріол, гемокапілярів, розширенням закапілярних венул та венул, змінами ангіоархітектоніки мікросудин, венозним повнокров'ям, гіпоксією, дистрофією, некробіозом клітин і тканин, інфільтративними та склеротичними процесами.

Перспективи подальших досліджень. Всебічне адекватне дослідження особливостей ремоделювання гемомікроциркуляторного русла сім'яників при дії на організм рубоміцину гідрохлориду сприятиме покращанню діагностики, корекції та профілактики ускладнень після введень в організм вказаного медикаментозного препарату.

при патології / Л. П. Горальський, В. Т. Хомич, О. І. Кононський. - Житомир : Полісся, 2011. - 288 с.

6. Грицуляк Б. В. Орхоепідидиміт / Б. В. Грицуляк, А. М. Спаська, В. Б. Грицуляк. - Івано-Франківськ : Прикарпатський національний університет, 2010. - 188 с.

7. Morphometric analysis of peculiarities of the testicular arteries remodeling under the influence of rubomycin hydrochloride / S. O. Konovalenko, M. S. Hnatiuk, O. B. Yasinovskyi, L. V. Tatarchuk // Polish Science Journal. - 2019. No. 11. - P. 77-83.

8. Лапач С. Н. Статистические методы в медикобиологических исследованиях Excell / C. Н. Лапач, А. В. Губенко, П. Н. Бабич. - Киев: Морион, 2001. - 410 с.

9. Резніков О. Г. Загальні етичні принципи експериментів на тваринах / О. Г. Резніков // Ендокринологія. 2003. - T. 8, № 1. - С. 142-145. 
Огляди літератури, оригінальні дослідження, погляд на проблему, випадок з практики, короткі повідомлення fluence of rubomycin hydrochloride. Polish Science Journal, 11, 77-83.

8. Lapach, S.N., Gubenko, A.V., \& Babich P.N. (2001). Statisticheskiye metody $v$ mediko-biologicheskikh issledovaniyakh Excell [Statistical methods in Excel biomedical re-

search]. Kyiv: Morion [in Ukrainian].

9. Reznikov, O.H. (2003). Zahalni etychni pryntsypy eksperymentiv na tvarynakh [General ethical principles of animal experiments]. Endokrynolohiia - Endocrynology, 8 (1), 142-145 [in Ukrainian].

\title{
МОРФОМЕТРИЧЕСКАЯ ОЦЕНКА ОСОБЕННОСТЕЙ РЕМОДЕЛИРОВАНИЯ ГЕМОМИКРОЦИРКУЛЯТОРНОГО РУСЛА СЕМЕННИКОВ ПРИ ДЕЙСТВИИ НА ОРГАНИЗМ РУБОМИЦИНА ГИДРОХЛОРИДА
}

\author{
ФМ. С. Гнатюк, С. О. Коноваленко, Л. В. Татарчук
}

Тернопольский национальный медицинский университет имени И. Я. Горбачевского Мз Украины

РЕзЮМЕ. Известно, что рубомицин - противоопухолевый антибиотик с выраженным цитостатическим действием широко используется в клинике. Применение данного медикаментозного вещества у мужчин может осложниться азооспермией, в морфогенезе которой важная роль отводится гемомикроциркуляторному руслу семенников.

Цель - провести морфометрический анализ особенностей ремоделирования сосудов гемомикроциркуляторного русла семенников при воздействии на организм рубомицина гидрохлорида.

Материал и методы. Морфометрически исследовано гемомикроциркуляторное русло семенников 60 белых крыс-самцов, которые были поделены на две группы. 1 группа включала 30 интактных животных, 2 - 30 крыс, которым однократно внутрибрюшинно вводили рубомицина гидрохлорид в дозе 30 мг/кг. Эвтаназию опытных животныхосуществляли кровопусканием вусловияхтиопенталового наркозачерез месяц от начала эксперимента.

Морфометрически определяли диаметры артериол, прекапиллярных артериол, гемокапилляров, посткапиллярных венул, венул и плотность микрососудов на 1 мм² семенников. Количественные показатели обрабатывали статистически.

Результаты. Выявлено, что морфометрические параметры микрососудов гемомикроциркуляторного русла семенников при воздействии на организм рубомицина гидрохлорида существенно изменялись. Диаметр артериол семенников при этом уменьшился на 17,0 \%, прекапиллярных артериол - на 22,4 \%, гемокапилляров - на $15,8 \%$ (р<0,001), а просвет поскапиллярних венул расширился на $31,1 \%$, венул - на 26,8\%, плотность микрососудов уменьшилась на 27,2 \%. Обнаруженное свидетельствовало об ухудшении кровоснабжения исследуемого органа. Светооптически подавляющее большинство венозных сосудов гемомикроциркуляторного русла неравномерно расширены, варикозно изменены, с частыми саккуляциями, переполнены форменными элементами крови, с явлениями стаза, тромбоза, что свидетельствовало о выраженном нарушении их дренажной функции. Венозный застой в исследуемых сосудах приводил к усилению гипоксии, дистрофии и некрозов эндотелиоцитов, миоцитов, сперматогенных эпителиоцитов, стромальных структур, инфильтративных и склеротических процессов.

Выводы. Введение в организм подопытных животных рубомицина гидрохлорида приводит к выраженному ремоделированию сосудов гемомикроциркуляторного русла семенников, характеризующегося выраженным сужением просветов артериол, прекапиллярных артериол, гемокапилляров и расширением посткапиллярных венул и венул, изменениями ангиоархитектоники микрососудов, венозным полнокровием, гипоксией, дистрофией, некробиозом клеток и тканей, инфильтративными и склеротическими процессами.

КЛЮЧЕВЫЕ СЛОВА: рубомицина гидрохлорид; семенники, гемомикроциркуляторное русло.

\section{MORPHOMETRIC EVALUATION OF PECULIARITIES REMODELING OF HEMOMICROCIRCULATORY BED OF THE TESTES AT THE ACTION ON THE BODY OF RUBOMYCIN HYDROCHLORIDE}

\author{
I. Horbachevsky Ternopil National Medical University
}

@M. S. Hnatyuk, S. O. Konovalenko, L. V. Tatarchuk

SUMMARY. It is known that rubomycin - an antitumor antibiotic with pronounced cytostatic action is widely used in the clinic. The use of this drug agent in men can be complicated by azoospermia, in the morphogenesis of which the hemomicrocirculatory bed of the testes plays an important role.

The aim - to conduct morphometric analysis of remodeling features of the hemomicrocirculatory beds of the testes when exposed to rubomycin hydrochloride.

Materials and Methods. Morphometric study of the hemomicrocirculatory bed of the testes of 60 white male rats, which were divided into two groups. The group 1 consisted of 30 intact animals, group $2-30$ rats, which were administered intraperitoneally with rubomycin hydrochloride at a dose of $30 \mathrm{mg} / \mathrm{kg}$. Euthanasia of experimental animals was carried out by bloodletting of thiopental anesthesia a month after the beginning of the experiment. 
Огляди літератури, оригінальні дослідження, погляд на проблему, випадок з практики, короткі повідомлення

The diameters of arterioles, precapillary arterioles, hemocapillaries, capillary venules, venules, and microvascular density per $1 \mathrm{~mm}^{2}$ tissue of testes were morphometrically determined. Quantitative indicators were processed statistically.

Results and Discussion. It was established that the morphometric parameters of the microvessels of the hemomicrocirculatory bed of the testes under the influence on the body of rubomycin hydrochloride were changed significantly. Diameter of arterioles of the testes decreased by $17.0 \%$, precapillary arterioles - by $22.4 \%$, hemocapillariesby $15.8 \%$ ( $p<0.001)$, and the lumen of the capillary venules expanded by $31.1 \%$, venules - by $26.8 \%$, microvascular density decreased by $27.2 \%$. The revealed evidence of deterioration of blood supply of the investigated organ. The optically vast majority of the venous vessels of the hemomicrocirculatory bed are irregularly expanded, varicosally altered, with frequent sacculation, overflowing with blood cells, with the stasis, thrombosis, which indicated a pronounced violation of their drainage function. Venous congestion in the vessels studied led to an increase in hypoxia, dystrophy and necrosis of endothelial cells, myocytes, spermatogenic epitheliocytes, stromal structures, infiltrative and sclerotic processes.

Conclusions. Introduction into the body of experimental animals rubomycin hydrochloride leads to a pronounced remodeling of the blood vessels hemomicrocirculatory beds of the testes, which is characterized by a pronounced narrowing of the arterioles, precapillary arteriolts, hemocapillaries, and extensions of the postcapillary venules, venules, changes in angioarchitectonics of microvessels, venous plethora, hypoxia, dystrophy, necrobiosis of cells and tissues, infiltrative and sclerotic processes.

KEY WORDS: rubomycin hydrochloride; testes; hemomicrocirculatory bed. 